\title{
Yaratıcı Drama Yöntemi ile Fatıma Sharafeddine'nin “Küçük Kız” Adlı Öyküsünden Hareketle Kadının Kimliğini Fark Etmesi
}

\author{
Nami Eren Beştepe ${ }^{1}$ \\ Tuba Çay Sağlam²
}

\begin{abstract}
$\ddot{O} z$
Bu çalışmada, Fatima Sharafeddine'nin “Küçük Kız” öyküsünden yola çıkarak kadın kimliğinin fark edilmesini sağlamak yaratıcı drama yöntemiyle ele alınmıştır. Çalışmaya Adana Selcen Hatun Anaokulu velilerinden 12 kadın veli katılmıştır. Çalışmada nitel araştırma yöntemlerinden görüşmeden yararlanılmış olup, soru formu, mektup ve görüşme kayıtları gibi nitel veri toplama araçlarından yararlanılmıştır. Verilerin betimsel ve içerik çözümlemeleri yapılmıştır.

Çalışmanın sonucunda, başlangıçta katılımcıların kadının kimliğinin ve ona yüklenen rollerin farkında oldukları ve bu rollerine ilişsin içinde bulundukları durumu da olağan, doğal buldukları görülmüştür. Çalışmanın sonlarında, katılımcıların, çocuklarına, eşlerine ve ailelerine karşı sorumluluklarının doğal olduğunu ancak, kendi isteklerini, beklentilerini, mutluluklarını çocukları, eşleri ve aileleri için göz ardı ettikleri, ikinci plana attıklarını dile getirmişlerdir. Bununla birlikte, hem çocuklarının ve ailelerinin beklentilerine karşı sorumluluklarını yerine getirebileceklerini hem de kendi istek ve beklentilerini ikinci plana atmadan, onları gerçekleştirmelerine yönelik çabalamaları gerektiğini belirtmişlerdir. Tüm sorumluluklarının yanı sıra kendilerine de zaman ayırmaları gerektiğini vurgulamışlardır. Ayrıca yaratıcı drama yönteminin, kadın çalışmalarıyla ilgili konularda uygun ve yararlı bir yöntem olduğu görülmüştür.
\end{abstract}

Anahtar Sözcükler: Kadın kimliği, Kendini fark etme, Yaratıcı drama.

\section{The Recognition of Women's Identity with Creative Drama (Based on The Story "The Little Girl” by Fatima Sharafeddine)}

\begin{abstract}
In this study, the recognition of women's identity was studied by Fatima Sharafeddine's story "The Little Girl" with the creative drama method. Twelve women parents from Adana Selcen Hatun Kindergarten attended at this study. In this study, qualitative research methods as well as questionnaires, letters an records of interviews were used. The description and content analysis of the data was done. At the end of the study, it was found that the attendants were aware of the identity and the roles loaded on women and they also thought it as a natural by means of the situation in which they were. At the end of the study it was concluded that the attendants were aware of their responsibilities toward their spouses, children and parents, but at the same time, they also stated that they neglected their expectations, happinness and wishes fort he sake of their spouses and children. At the same time, they stated that they should be able to tackle the problem by responsing to both the their own expectation of their families' and chilhdren's and to their own expectations without neglecting the two sides. They also stated that in addition to all their responsibilies they should also spend some spare time for themselves as well. Furthermore, it was concluded that the creative drama methods was seen as a convenient and useful method related to research on women.
\end{abstract}

Keywords: Identity of women, Recognition of yourself, Creative drama.

Yrd. Doç. Dr. Mustafa Kemal Üniversitesi. Eposta: nbestepe@gmail.com

2 Ögrretmen, Selcen Hatun Anaokulu. Eposta: t.cay@mynet.com 


\section{Giriş}

Kadın ve erkek tarih boyunca birlikte vardır. Kimi yaklaşımlara göre birbirlerine göre benzerlikleri ve farklılıkları bulunur. Toplumsal yaşamda ya da günlük yaşamda ele alınış biçimiyle, tartı̧̧malı da olsa daha çok farklılıkların dile getirildiği söylenebilir. Burada temel noktalardan biri cinsiyet terimidir. Cinsiyet terimi, "kadın ya da erkek olmanın biyolojik yönünü ifade eder ve biyolojik bir yapıya karşılık gelir.” (Dökmen, 2010, s.19-20). Bir diğer kullanılan terim ise toplumsal cinsiyet terimidir. Toplumsal cinsiyet terimi ise, kadın ya da erkek olmaya toplumun ve kültürün yüklediği anlamları ve beklentileri ifade eder; kültürel bir yapıyı karşılar ve genellikle bireyin biyolojik yapısıyla ilişkili psikolojik özelliklerini de içerir.” (Dökmen, 2010, s.20).

Dökmen (2010, s.25)'e göre, “biyolojik cinsiyet, farkları öğrenilmemiş, doğuştan getirilen özellikler bakımından kadınlarla erkekler arasında gözlenen farklılıklardır. Toplumsal cinsiyet farklılıkları ise öğrenilen, sosyalleşme sürecinde kazanılan özellikler bakımından insanlar arasında gözlenen farklılıklardır." Kadın ve erkeğe birbirinden farklı ve toplumdan topluma, kültürden kültüre değişebilen roller de yüklenir. Dökmen'e (2010, s.29) göre, "kadınlara ve erkeklere verilen farklı roller toplumsal cinsiyet rolleri olarak bilinir. ...Toplumsal cinsiyet rolleri terimi, cinsiyet kalıp yargılarını ya da toplumun belirlediği cinsiyet farklılıklarını yansıtmak üzere kullanılır.”

Yılmaz ve arkadaşları (2009, s.777)'na göre, “Toplumsal cinsiyet rolleri, kadın ve erkeğin özellikle çalışma yaşamı, toplumsal yaşam, evlilik ve aile yaşamındaki rollerinde belirgin farklılıklar göstermektedir. Toplumsal cinsiyet rollerinin çalışma yaşamına ilişkin yansımaları incelendiğinde; kadınlara statüsü ve ücreti daha düşük işlerde çalışma, çalışmak için eşlerinden izin almaları gibi roller uygun görülmektedir. Toplumsal yaşamda; kadınların akşamları tek başına sokağa çıkmamaları, kadınların yalnız yaşamamaları gibi yargılar bulunmaktadır. Aile yaşamına bakıldığında; kadınlardan eşlerinden şiddet görüyorlarsa bu durumu saklamaları, ev içinde çocuk bakımı, temizlik gibi işlerle ilgilenmeleri beklenmektedir. Toplumumuzda egemen olan anlayışa göre, kadının yeri evidir ve asli görevi ev işi yaparak kocasına ve çocuklarına bakmaktır (Kuzgun ve Sevim, 2004, s.15). Carnaghan ve Bahry (1990), kadınların kendilerine ilişkin algılarının davranışlarını da etkileyeceğini vurgulamışlardır. Bu faaliyetlerin çoğu günlük yaşamın temelidir (Akt. Güldü ve Ersoy-Kart, 2009, s.99).

Kadın kimliğine yüklenen bu toplumsal rollerin kimi ev kadınları için günlük yaşam içinde kanıksandığı, sıradanlaştığı; ev kadınlarının kendi isteklerini, beklentilerini ikinci plana iterek doğal bir süreç gibi bu rolleri kabullendiği düşünülebilir. Kadın olarak kimliğinin farkında olmasıyla birlikte kimi kadınlarda, kendisine yüklenen bu toplumsal cinsiyet rolleri ile kendini sadece çocuklarının ve eşinin mutluluğuna adayan, doğal bir durum gibi kendi isteklerini, mutluluğunu ikinci plana iten bir davranış izlenebilir. Oysaki kendinin, varlığının ve kimliğinin farkında olan kadın, kendi beklentilerini ve mutluluğunu gerçekleştirmeye çalışırken de çocuklarını, eşini ve ailesini mutlu edebilir, onların gereksinimlerini karşıllayabilir. Kuşkusuz bu mutlu etme ve gereksinimlerini karş1lama, eşlerin ve aile bireylerinin karşılıklı sorumlulukları olmalı, sadece kadının sorumluluğu olmamalıdır.

Kimi zaman kimi kanıksanmış, doğallaşmış durumları, olayları, yaşantıları vb. şeyleri kişilerin fark etmesine ya da farkına varmasına olanak sağlamak gerekebilir. Böyle bir durumda başvurulacak yollardan bir tanesi de yaratıcı dramadır. İnsanın bireysel ve toplumsal sorunlar üzerinde düşünmesine yardım etmenin bir yolu da dramadan geçer. Drama aracılığıyla olaylar ve 
durumlarla bunların arasındaki bağlantılar kolayca öğrenilebilir (Üstündağ, 2006, s.242; O’Neill ve Lambert, 1989). Yaratıcı drama, kişinin, olayları, durumları yaşayarak, deneyerek, kendi katılımıyla birinci elden deneyimlemesine olanak sağlar.

Adıgüzel (2012, s. 55-56) yaratıcı dramayı, "bir grupla ve grup üyelerinin yaşantılarından yola çıkarak, bir amacın, düşüncenin, doğaçlama, rol oynama vd. tekniklerden yararlanarak canlandırılmasıdır" şeklinde tanımlar. Tanımda öne çıkan özelliklerden biri, yaratıcı dramanın grupla gerçekleştirilmesi ve çalışılacak temanın ne olursa olsun grup üyelerinin yaşantılarından yola çıkarak ele alınmasıdır. Böyle bir süreçte katılımcı, ilgili konu ile yaşantılarını ilişkilendirebilir, yine kendi yaşantıları ile diğer grup üyelerinin yaşantılarını ilişkilendirerek karşılaştırabilir. Bunun yanı sıra diğer grup üyelerinin konu ile ilgili yaşantılarını, birikimlerini izlerken konu ile ilgili kendisini de gözlemleyebilir. Tüm bunlar yukarıda da belirtildiği gibi katılarak, deneyerek, yaşayarak gerçekleştirilir. Yaratıcı drama süreçlerinde konu ele alınırken çeşitli malzemelerden de yararlanılabilir. Bu malzemeler ipuçları, bakış açıları gibi ek desteklerle konunun daha rahat çalışılmasını, irdelenmesini sağlayabilir.

Tüm bunlardan hareketle; yaratıcı drama yöntemiyle kadının yüklendiği roller çerçevesinde kendini, isteklerini ve mutluluğunu, çocukları, eşi, ailesi vb. diğer kişiler karşısında ikinci plana atıp atmadığı konusunda bir fark etme çalışması planlanmaya çalışılmıştır.

\section{Çalışmanın Amacı}

Çalışmanın amacı, yaratıcı drama yöntemi ile işlenen Fatma Sharafeddine’in Küçük Kız adlı öyküsü aracılığıyla katılımcılarda kadın kimliğine ilişkin farkındalık oluşturarak kadınların kendi kimliklerini fark etmelerine katkıda bulunmaktır.

\section{Çalışmanın Yöntemi}

Yaratıcı drama yöntemi ile işlenen Fatma Sharafeddine'in Küçük Kız adlı öyküsü aracıllı̆ı̀yla katılımcılarda kadın kimliğine ilişkin farkındalık oluşturmayı amaçlayan bu çalışmada, nitel araştırma yöntemi kullanılmıştır. Uygulama sürecinde nitel araştırma yönteminin veri toplama araçlarından görüşme kullanılmış olup, soru formu, mektup gibi nitel veri toplama araçlarından da yararlanılmıştır.

\section{Çalışma Grubu}

Çalışma grubu, Adana Selcen Hatun Anaokulu velileri arasından gönüllü on iki kadın katılımeıdan oluşmaktadır. On bir katılımeı lise mezunu, bir katılımcı da üniversite mezunudur. Katılımcılar 28 - 35 yaş aralığında olup, çoğu iki çocuk annesidir. Öğretmenlik yapan üniversite mezunu katılımcı dışında hepsi ev hanımıdır. Sağlık vb. nedenlerden dolayı beşinci oturuma 9, altıncı oturuma da 10 katılımcı katılmıştır. Katılımcıların hiçbirinin daha önceden yaratıcı drama ile ilgili deneyimi bulunmamaktadır.

\section{Veri Toplama Araçları}

Çalışmada nitel veri toplama araçlarından yararlanılmıştır. Bunlardan ilki, birinci oturum öncesi katılımcılara yanıtlamaları için sunulan, yapılandırılmamış dört sorudan oluşan soru formudur. İkinci veri toplama aracı, beşinci oturumun sonunda katılımcılardan "kendi ben'lerine" yazmaları istenen mektuptur. Üçüncüsü de altıncı oturumdan sonra yapılan grup görüşmesinde kayıt altına alınan katılımcı görüşleridir. 


\section{Verilen Çözümlenmesi}

Araştırma kapsamında ulaşılan verilerin analizinde içerik analizi ve betimsel analiz kullanılmıştır. Birinci oturum öncesi sunulan soru formundan elde edilen katılımcı görüşleri, dört tema altında; altıncı oturum sonunda yapılan grup görüşmesinde kayıt altına alınan katılımcı görüşleri de yine dört tema altında irdelenip betimsel çözümlemeleri yapılmıştır. Beşinci oturum sonunda oturuma katılan 9 katılımcının yazdı̆̆ı mektupların içerik çözümlemesi yapılmıştır. Mektuplar okunarak incelenmiş, mektuplar üzerinde kodlama yapılarak, mektuplarda geçen sözcükler ve sıklıkları belirlenerek tablolaştırılmıştır. Katılımcıların görüşleri, belirlenen kodlardan hareketle oluşturulan altı tema altında yorumlanmaya çalışılmıştır.

\section{Uygulama Süreci}

Kadınların, kadın kimliğinin yüklendiği roller çerçevesinde, diğer kişilerin istekleri ve mutlulukları karşısında kendilerini gerçekleştirmeyi ikinci plana atıp atmadıklarını fark etmelerini amaçlayan bu çalışma, Adıgüzel (2012) tarafindan oluşturulan 1sınma, canlandırma ve değerlendirme aşamaları temel alınarak planlanan yaratıcı drama oturumları ile yapılandırılmıştır. Uygulama oturumları planlanırken Fatima Sharafeddine'nin "Küçük Kız" adlı öyküsü (Ek.1) temel alınmıştır. Uygulama süreci iki tam saatten oluşan altı oturum olarak planlanmıştır. Oturum içerikleri genel olarak şöyledir:

\section{Birinci Oturum: Tanışma}

Birinci oturumda, yaratıcı drama atölyesine ilk kez katılan katılımcıların hem yaratıcı dramaya karşı hem de diğer katılımcılara karşı olası çekiniklerini ortadan kaldırmaya dönük etkinlikler yapılmıştır. Bu oturumda ağırlıklı olarak isim-tanışma oyunları, kaynaşma, iletişimetkileşim etkinliklerine ve uyum-güven çalışmalarına yer verilmiştir.

İkinci Oturum: Duygularım

$\mathrm{Bu}$ oturum, duyguları fark etme, hatırlama, kadınların duyguları üzerinedir. $\mathrm{Bu}$ nedenle katılımcılar, kadın portrelerinden oluşan bir sergiye davet edilirler; serginin kendilerine hissettirdiklerini de göz önüne alarak sergiye isimler bulurlar. Gruplara ayrılan katılımcılar, grup arkadaşlarıyla kendilerini etkileyen portreyi konuştuktan sonra beraber üzerine canlandırmalar yapacakları portreyi seçerler. Önce kadının sosyal hayatla ilgili ilişkileri üzerine (ailesi, iş arkadaşları, eşi, komşusu vb.) daha sonra da bu kadının farklı duygu durumlarıyla ilgili (endişeli, kaygıllı, mutlu vb.) canlandirmalar yaptılar.

\section{Üçüncü Oturum: Küçük Kızın Evi}

Üçüncü oturumda, “Ben kimim?” oyunundan sonra lider katılımcıları küçük bir kızla tanıştırmak istediğini söyler ve öyküden kısa bir bölüm okuyarak kahramanla tanış1lır. Bu oturum, katılımcıların sürece daha fazla dahil olmaları, kendi yaşanmışlıklarını da işin içine katmaya başlamaları da düşünülerek "küçük kız'ı” oluşturma aşaması olarak düşünülmüştür. Kıza bir kimlik oluşturulmaya çalışılmıştır. Olası isimler nedenleriyle düşünülmüş, yine olası yaşam senaryoları üzerine konuşulmuş ve küçük kızın kuklası oluşturulmuştur. Daha sonra bu kıza (ki adı katılımcılar tarafından "Kader" olarak belirlenir) ait bir ev hazırlanmıştır. 
Dördüncü Oturum: Vermek İyi Hissettiriyor

$\mathrm{Bu}$ oturumun canlandırmalarına öyküden yola çıkılarak başlanır. Katılımcılar öncelikle Kader'in yaşamında verici davrandığı noktaları öyküden yola çıkarak belirlerler ve bunlar gruplarca canlandırılır. Daha sonra kendi yaşamlarında verici oldukları durumlar gruplarca canlandırılır. Oturum sonunda katılımcılar ile kadınların neden daha verici ve fedakar olduğu, bunun psikolojik, biyolojik ve toplumsal nedenleri ile kadının vererek aslında var olmaya mı çalıştığı ve kendi yaşamlarının da birilerine verilip verilmediği üzerine sözlü değerlendirmelerde bulunulur.

Beşinci Oturum: İnsan Nasıl ve Neden Mutlu Olur?

$\mathrm{Bu}$ oturumda, insan neden ve nasıl mutlu olur soruları önce "Kader" üzerinden irdelenir. Öykünün ilgili bölümleri okunduktan sonra Kader'in "Neden mutlu değilim?" sorusuna bilinç koridoruyla cevaplar aranarak ilgili canlandırmalar yapılır. Kadınların mutsuzluk nedenleri ve toplumdan, ailelerinden, eşlerinden, yaşamdan istedikleri, "kendisini yok sayarcasına memnun edenler" kulübü manifestosunda ve grupların basın toplantısında tartış1lır. Son olarak bu oturum, katılımcıların bu güne kadar irdelenenleri göz önünde bulundurarak içlerine dönmeleri ve kendi "ben"lerine bir mektup yazmalariyla son bulur.

Altıncı Oturum: Hayır Diyebilmek

Son oturum, kadının ilişkilerinde "hayır" diyebilmesi üzerine kurulmuştur. Dördüncü oturumda katılımcıların da yaşamlarında karşılaşabilecekleri ve fedakarlık gösterecekleri canlandırma konuları aynen alınır, fakat katılımcılardan bu fedakarlığı kabul etmemeleri, canlandırmaları "hayır diyebilmek" temasıyla sürdürmeleri istenir. İkinci olarak katılımcılar kendi yaşamlarında hayır diyemedikleri şeyleri grup arkadaşlarıyla tartışırlar, bunlardan birisini seçerek canlandırırlar.

\section{Bulgular ve Yorum}

\section{Soru Formundan Elde Edilen Verilerin Değerlendirilmesi}

Birinci oturum başlamadan katılımcılara, yapılandırılmamış dört sorudan oluşan bir form verilmiş ve bunları yanıtlamaları istenmiştir. Bu sorular yanıtlanırken araştırmacı tarafından gerek duyulduğunda ya da katılımcılardan talep geldiğinde açılamalar yapılmıştır. Katılımcıların her soru için verdikleri yanıtlar, tema olarak kabul edilen soruların altında bir araya getirilmiştir. Katılımcıların yanıtlarında konu ile doğrudan ilgisi bulunmayan ifadeler çıkarılmış, ifadelerin çıkarıldı̆̆ 1 yerler kısaltma işareti ile gösterilmiştir. Temaların altında bir araya getirilen veriler, betimsel çözümleme ile irdelenmeye çalışılmıştır.

\section{“Kadın Olmak Sizin İçin Ne ifade Ediyor?” Teması}

K.1: Sorumluluk, emek vermek, mücadele.

K.2: Kadın olmak güçtür. Her şeye rağmen ayakta durmaktır. Kadın olmak yeri geldiğinde sakince durup sabretmek ve içinde ruhunda zenginlikler ve güzellikler gizlemektir...

K.3: Aile olmak, anne olmak.

K.4: Hayatın zorluklarl, güçlü yaşam, sorumluluk alma ve her şeyden ödün verme.

K.5: ...Polyanna gibi yaşarken çocuğunla beraber kadın olduğunu anllyorsun. Bununla beraber büyük sorumluluklar, görevler, başarllar, istekler, hayaller ... çok şeyler. 
K.6: Kadın olmak büyük sorumluluk gerektiriyor. Evlilik, daha sonra anne oluyorsunuz. Hepsinin ayr bir sorumluluğu var. Ama zor değil, hepsinin üstesinden geliyorum.

K.7: Kadın olmak zor bir süreci başarıyla tamamlayabilmek benim için.

K.8: Hayatın tüm yükünü çekmeyi.

K.9: Erkeklerin kesinlikle her konuda muhtaç oldukları bir bireydir kadın. Kadınsız bir ev düşünemiyorum. Baba evin direği derler ya, bana göre kadın evin direğidir. Kadın olmak fedakar olmaktır, ana olmaktır.

K.10: Anne olduğumuz zaman bir tarafa ittiğimiz. Sevip sevilmek isteyen, ilgiye hiç doymayan; hep daha iyisini yapmaya, hep daha iyi olmaya çalışan insan.

K.11: Özel bir duygu. Çünkü, kadın olmak anne olabilmek demek. Bunun yanında fedakarlığın, sabrın, şefkatin en büyüğ̈̈ne sahip olmaktır.

K.12: En önemlisi de anne olmayl.

"Kadın Olmak Sizin İçin Ne ifade Ediyor?” teması altında toplanan katılımcı görüşleri incelendiğinde, kadın olmak kavramıyla; sorumluluk alma, emek vermek, mücadele etmek, güçlük, güçlü olma, ödün verme, fedakarlık ve anne olma gibi ifadeler ilişkilendirilmiştir. Bu bağlamda, kadının kendisinden çok, kendisi dışındaki kişiler için harcadığı çabanın öne çıktığı düşünülebilir.

\section{"Hayatınızı Kime / Neye Göre Yaşıyorsunuz?” Teması}

K. 1: Hayatımı çocuklarıma ve eşime göre yaşlyorum. Tamamen onlara adapteyim. Kendime ait özel hiçbir şeyim yok.

K.2: Belli bir yaşa gelinceye kadar annemin isteklerine göre yaşadım; aslında hep annemin isteklerine göre yaşadım. Evlilikte de eşimin, annemin ve toplumun isteklerine göre yaşadım.

K.3: Oğluma ve tüm sevdiklerime göre.

K.4: Daha önce hayatımın öncelikleri hep başkalarlydl. Şu anda ise daha çok kendim ön planda. Çünkü ben çok değerliyim. Kendime daha çok zaman ayırmalıyım ki başkalarına, en çok da oğluma daha fazla katkım olsun.

K.5: Artık size bağlı olan bazı bireyler var (çocuk, eş). Onlarla bir hayat yaşıyorsunuz. Onların ihtiyaçları, istekleri doğrultusunda bir hayat başlıyor.

K.6: Öncelikle kendim, eşim ve çocuklarım için yaşıyorum.

K.7: Şu an iki evladım var. Öncelikli kimliğim tabii ki annelik. Onlar için en iyisini yapmaya çalışıyorum. Sadece kendime ayda iki ya da üç defa zaman ayırabiliyorum.

K.8: Çocuklarım için.

K.9: Hayatımı önce çocuklarım için, çocuklarıma göre yönlendiriyorum. Hayatımın olmazsa olmazları çocuklarım. Onların isteklerine ve beklentilerine göre hayatımı yaşıyorum ve evim için, ailem için.

K.10: Eşim ve çocuklarıma göre yaşlyorum. Yapacağım her şeyi onlara göre planlyyorum. Öncelik onların rahatı ve mutluluğu. Onlar mutlu iken ben de mutluyum.

K.11: Hayatımda var olmamın en büyük sebebi başta evladım, kardeşlerim ve eşim. 
"Hayatınızı Kime / Neye Göre Yaşıyorsunuz?” teması altında toplanan katılımcı görüşleri incelendiğinde, katılımcıların genel olarak çocuklarına ve eşlerine göre yaşamlarını kurguladıkları görülmüş̧ür. Bir katılımcı kendisine göre de yaşadığını ifade ederken, bir katılımcı da (K.4) kendisini ön planda tutarken dolaylı olarak yine çocuğuna katkı sağlamayı öne çıkarmıştır.

\section{"Hayatınızı Kim / Kimler İçin Yaşıyorsunuz?” Teması}

\section{K.1: Çocuklarım için.}

K.2: Anne olduktan sonra çocuklarım için yaşıyorum.

K.4: En çok oğlum ve değer verdiğim insanlar için.

K.5: Hayatımı tabii ki kendim ve çocuğum için yaşıyorum.

K.6: Kendim ve ailem için yaşıyorum

K.7: Hayatımı ikinci bebeğim doğmadan önce daha savurgan ve kontrolsüz yaşlyordum. Bir gün karar verdim. Zamanı şimdi daha iyi kullanmaya çalışlyorum. Kendi aileme, eşimin ailesine ve arkadaşlarıma çok daha fazla zaman ayırıyorum.

K.8: Çocuklarım için.

K.9: Hayatımda çocuklarım her şeyden ve herkesten önce gelir. Kendime pek zaman ayıramıyorum. Kendimden önce bile onlar geliyor benim için.

K.11: Hayatımı, bana en yakın, samimi, fedakar, özverili bulduğum herkes için yaşıyorum. Öncelik tabii ki ailem. Kendimde isteyip te yapamadı̆̆ım, keşke dediğim her şeyi evladımın hayatında başardı ğını görerek onunla uzun yıllar yaşamak istiyorum.

K.12: Bir yıl öncesine kadar kendim ve oğlum içindi. Fakat kalabalık bir aileyiz. Onların bana ihtiyacı olduğunda ve duyarsız kalamadı̆̆ımdan, onlar için de yaşamam gerekiyor.

"Hayatınızı Kim / kimler için yaşıyorsunuz?" teması altında ele alınan katılımcı görüşleri incelendiğinde, katılımcıların genelinde ortak olan "çocuklarım için yaşıyorum.” ifadesidir. İki katılımcı (K.5, K.6) "kendim için yaşıyorum” ifadesini de kullanmıştır. Üç katılımcının görüşlerinde "ailem için yaşıyorum” ifadesi de görülür. Ailem için ifadesinde eş ve yine çocukların olduğu söylenebilir. Katılımcıların çoğunun kendilerini ikinci planda tuttukları söylenebilir.

“Sadece Kendiniz İstediğiniz İçin Yaptığınız Şeyler Hayatınızda Ne Kadar Yer Tutar? Bunlardan örnekler verebilir misiniz?” Teması

\section{K.1: Birkaç saat tutabilir.}

K.2: Çok az yer tutar. Diyebilirim ki kuaföre gitmek ve bahçeyle uğraşmak dışında kendim için özel bir şey yapmıyorum. Özel ya da bireysel yaptı̆̆ım hiçbir şey yok.

K.3: Ben istediğim sürece ve eşim izin verdiği sürece arkadaşlarımla yemeğe gitmek, sinemaya gitmek $v b$.

K.5: Sadece kendim istediğim için yaptığım şeyler hayatımda büyük yer tutar. Örneğin bir musiki derneğine 10 yıldır devam ediyorum. Bu en azından sadece kendim için yapmış olduğum bir şey. Salı ve Perşembe günleri 18.30-20.30 benim saatim, sadece ben zevk alip, ben mutlu oluyorum. 
K.6: Kendim için mutlaka bir zamanım vardır. İki çocuk annesi olduğum için yoğun tempoda hayatım var. Hepsine yetiştiğim gibi kendime de vakit ayırabiliyorum. Film izlemek, kitap okumak, kahve içmek ve gezmek.

K.7: Ayda en fazla 4-5 gün tutabilir hayatımın kendime ait kısmı. Sorumluluklar ön planda oluyor ama kadın olmak böyle bir şey işte. Önce ben demek her zaman olmuyor.

K.8: Çok az yer tutar.

K.9: Aslında pek doğru mudur bilmiyorum ama kendi isteklerim ikinci planda geliyor. Çocuklarım daha ăgır basiyor

K.10: Sabah kahvem 10 dakika. Öğle uykum (çocukları uyutabilirsem) 1 saat. Akşam sporum 1 saat.

Bu tema altında sıralanan katılımcı görüşlerine bakıldığında, iki katılımcı dışında yaşamlarında kendileri için yaptıkları şeylerin çok az olduğu görülebilir. 5. katılımcı on yıldır kendi istediği için müzikle ilgilendiğini, 6. katılımcı ise kendine de zaman ayırdığını film izlediğini, gezdiğini, kitap okuduğunu belirtmiştir. 3. katılımcı da arkadaşlarıyla sinemaya gitmek ve yemek yemek gibi istediği şeyleri eşinin izniyle yaptı̆̆ııı belirtmiştir.

Tüm bu verilere bakıldığında aslında kadın kimliği ile ilgili olarak kendilerine yüklenen rolleri bildikleri, bunları uyguladıkları ve farkında oldukları söylenebilir. Ancak bu rollerin zaten böyle olduğu, bunun olağan, doğal bir durum olduğunu düşündüklerini söylemek de mümkündür.

\section{Katılımcı Mektuplarına İlişkin Bulgular}

Beşinci oturumun değerlendirme kısmında, bu güne kadar irdelenenlerle, katılımcılardan kendi "ben"lerine bir mektup yazmaları istenmiştir. Bu oturuma dokuz katılımcı katılmış ve dokuz mektup yazılmıştır. Bu mektuplardan elde edilen veriler incelenerek kodlamalar yapılmış, öne çıkan sözcükler ile sıklıkları belirlenmiş ve Tablo 1'de gösterilmiştir. Bu veriler, yapılan kodlamalar çerçevesinde oluşturulan "Çocuklar”, "Eş /Evlilik", "Mutluluk / Mutsuzluk", "Keşke / Pişmanlık”, "Kendi İsteklerini Gerçekleştirme / Gerçekleştirememe" ve "Söz Hakkı Olmama / Değer Görmeme" olmak üzere altı tema bağlamında açıklanmaya çalışılmıştır. Kodlamada öne çıkan sözcüklerin birbirleriyle ilişkileri göz önüne alınarak belirlenen temaların altında değerlendirilmesi uygun görülmüştür.

Tablo 1. Katılımcı Mektuplarının Içeriklerinin Kodlanmasındaki Sözcük Sıklık Listesi

\begin{tabular}{|l|l|l|l|l|l|l|l|l|l|l|}
\hline Sözcükler & K.1 & K.2 & K.3 & K.4 & K.5 & K.6 & K.7 & K.8 & K.9 & Top. \\
\hline Keşke & 9 & & & & & 1 & 1 & 1 & & 12 \\
\hline Pişmanlık & 1 & & & & & & 1 & & 3 & 5 \\
\hline Mutlu & 4 & 1 & & 1 & 2 & & & 1 & 1 & 10 \\
\hline Kendim & 2 & & 3 & 1 & 4 & & 1 & & 1 & 12 \\
\hline Ben & & & 2 & 1 & 1 & & & & 4 & 8 \\
\hline Çocuk & 2 & 2 & 1 & & 1 & 4 & & 3 & 8 & 21 \\
\hline Eşim/Kocam & 2 & 1 & & & 1 & & 1 & 1 & 3 & 9 \\
\hline Evlilik & 1 & 1 & 3 & & & 2 & 1 & & 1 & 9 \\
\hline Ĕğitim & 1 & & & & & 1 & 1 & & & 3 \\
\hline
\end{tabular}




\begin{tabular}{|l|l|l|l|l|l|l|l|l|l|l|}
\hline Meslek & 1 & 1 & & & & & & & & 2 \\
\hline Kadın & 2 & & 1 & & & & & & 1 & 4 \\
\hline $\begin{array}{l}\text { Aile (Kendi } \\
\text { Ebeveynleri) }\end{array}$ & 1 & & 4 & & & 4 & & 2 & & 11 \\
\hline Babam & & 2 & 1 & & & 2 & 3 & 2 & & 10 \\
\hline Annem & & 3 & 1 & & & 2 & & 4 & 5 & 15 \\
\hline Güven & 1 & & & & & & & 1 & & 2 \\
\hline Aşağılanmak & & 2 & & & & & 1 & & & 3 \\
\hline Hor görülmek & & 1 & & & & & 1 & & & 2 \\
\hline Değer verilmemek & 1 & & & & & & & & & 1 \\
\hline Söz hakkı & & & 2 & & & & & & & 2 \\
\hline Acı & & & 1 & 1 & & & & & & 2 \\
\hline
\end{tabular}

\section{“Çocuk" Teması}

Çalışmada katılımcıların “çocuk” teması altında ele alınabilecek kimi görüşleri şöyledir.

K.1: Şu an tek umudum çocuklarım.

K.2: Tek amacım çocuklarımı iyi yetiştirebilmek.

K.5: Hayatın sadece evden, eşten ve çocuktan ibaret olmadı̆̆ını daha yeni yeni öğrendim.

K.6: Hayatımı ben iki evreye ayırıyorum. Çocuklarımdan öncesi ve sonrası diye. Çocuklarımın benim gibi hissetmemesi ve yaşamaması için çabalıyorum. Her şeye rağmen çocuklarımla hayat güzeldir.

K.9: Anne oldun çok mutluydun. Hayatının dönüm noktasıydı o gün. Artık Polyanna (katılımcının adı), çılgın macera sever (katılımcının adı) gerilerde kaldı. Artık ikinci yaşamın başladı anne olmanla.

"Çocuk" teması ile ilgili katılımcı görüşleri incelendiğinde; çocukların, katılımcıların yaşamlarında önemli bir yer tuttuğu görülebilir. Ancak ifadelerden, bir ebeveyn sorumluluğunun dışında kendilerini ikinci plana attıkları, beklentilerini çocuklarında gerçekleştirmeye çabaladıkları, geleceğe ilişkin umudu çocuklarında besledikleri, kendilerini çocuklarına adadıkları ve bu durumlarının da farkında oldukları söylenebilir.

\section{"Eş /Evlilik" Teması}

Çalışmada katılımcıların "Eş / Evlilik” teması altında ele alınabilecek kimi görüşleri şöyledir.

K.2: Kendi mezhebin dışında kimseyle evlenemezsin dediler. Aşık olduğumda söyleyemedim. Görücü usulü evlendim.

K.1: Keşke evlenmeseydim dediğim çok anlar oldu. Ailemi kırmadan, onları ezmeden bir eş seçebilseydim. Kendi seçtiğim insanla olur diye düşündüm, ama yine mutlu olamadım.

K.3: Liseyi bitirdiğimde daha çok cahil ve küçük yaşta yanlış bir evlilik yaptım. Üç yıl sürdü ve faturasını çok ağır ödedim. ... Eşinden ayrılmış bir kadın olarak ailemin evinde de yine yaşamanın ne kadar zor olduğunu gördügü̈m için ikinci kez iki çocuklu biriyle evlendim.

K.5: Artık sadece eşim, ailem için yaşamayacağım. Çünkü çok yıprandım, yoruldum. Hayatın sadece evden, eşten, çocuktan ibaret olmadığını daha yeni yeni öğrendim.

K.6: Maalesef küçük yaşta evlenmek zorunda kaldım. Kaldım diyorum çünkü evliliğimde sorunlu 
başladl, sorunlu devam etti Allah 'tan sorunsuz bitti.

K. 7: Doğal olarak evliliğimde isteyerek olmadı. Hayalini kurduğum, topră̆ın suya susamış hali gibi sevgiye aç kaldım.

K.9: Artık ikinci ben olmanla görev sorumlulukların kanunlaştı. İyi bir anne, verimli bir anne, sonra aslında benim yitirdiğim fedakarlı̆̆ım, eşine olan görevlerini yerine getirme. Hepsini harfiyen yerine getirdim.

Katılımcıların "Eş/Evlilik” teması altında ele alınabilecek görüşleri incelendiğinde; iki katılımcı dışında evliliklerinin sorunlu olduğu, bir kısmının eşlerinin kendi tercihleri olmadığı, evliliklerine ilişkin keşkelerinin olduğu, yine de eşleri ile ailelerini mutlu etmeye çabaladıkları ve içinde bulundukları durumu ifade edebildikleri söylenebilir.

\section{"Mutluluk/Mutsuzluk" Teması}

Çalışmada katılımcıların "Mutluluk/Mutsuzluk" teması altında ele alınabilecek kimi görüşleri şöyledir.

K.2: Mutsuzum.

K.4: Çok acılar yaşadık, daha da yaşayacağız. (Ruhum) her şeye rağmen kötü olmadı̆̆ın, kimseyi kırmadiğın, üzmediğin, sevdiğin ve önemsediğin için teşekkür ederim... Çok verdik vereceğiz de bunun için mutluyum.

K.5: ...Ama artık kendimin ve gücümün farkındayım. Bundan sonra kendimi mutlu etmek için çaba harcayacă̆ım.

Katılımcıların "Mutluluk/Mutsuzluk” teması altında ele alınabilecek görüşleri incelendiğinde; çoğunun mutsuz oldukları, eş ve çocuklarını mutlu etmeye çabaladıkları ve durumlarının farkında olduklar1 söylenebilir.

\section{“Keşke/Pişmanlık” Teması}

Çalışmada katılımcıların "Keşke/Pişmanlık” teması altında ele alınabilecek kimi görüşleri şöyledir.

K.1: Keşke ile başladığım en büyük pişmanlığım eğitim hayatımı sürdürememiş olmam.

K.5: Yıllarımı kendime zaman ayırmadan geçirdiğim için zaman zaman çok pişmanlık duyuyorum.

K.6: Dertlerim, yaralarım, pişmanlıklarım, keşkelerim o kadar çok ki.

K.7: Hayatta keşke babamı, öğretmenimi ve eşimi seçebilseydim. Çünkü yaşamım boyunca bu pişmanlıkları yaşamak zorunda kaldım. ... Ömrümde tek içerlediğim şey herkesi kendimden yüce görmek, kendimi aşă̆llamak, herkese ödün vermek.

K.9: Birinci benin çok istekleri, çok hayalleri vardl. Olmak istedikleri şeyler çok farkliydl. Işste bu anlardan sonra pişmanlıklarım beni sarsıyor. Birinci ben ve ikinci ben çelişiyorum. Şu an sadece kendimle çelişiyorum; pişmanlıklar, vazgeçilmişler, falanlar, filanlar.

"Keşke / Pişmanlık” temasındaki sözcüklere bakıldığında, iki sözcüğün frekans toplamlarının yüksek olduğu; yapmak istedikleri ve yapamadıklarıyla ilgili keşkelerinin fazla olduğu görülüyor. Eğitimlerini istedikleri gibi sürdürememeleri, çoğunun meslek sahibi olamamaları ve çoğunun yaşamlarında kendi beklentilerini geride tutmaları konusunda pişmanlıklarının, keşkelerinin olduğu değerlendirmesi yapılabilir. 


\section{“Kendi İsteklerini Gerçekleştirme / Gerçekleştirememe" Teması}

Çalışmada katılımcıların "Kendi İsteklerini Gerçekleştirme / Gerçekleştirememe" teması altında ele alınabilecek kimi görüşleri şöyledir.

K.2: Okulun tiyatro topluluğunda çok başarılıydım. Rolümü ezberleyip belediye binasında gösterimiz olacaktı, ailem izin vermedi. Yüzmede lisanslı yüzücüydüm şehir dışına yarışmalara gönderemeyiz deyip aldular.

K.3: İstediğim hiçbir şeyi yapamıyorum. Evlendiğimden beri hayatım tamamen onlara göre planl.

K.6: Ly bi bir ĕgitim hayatım olmadı. Oysaki ne hayallerim vardl.

K.7: Babamin hep hor görmesi, aşağılaması, sizden hiçbir şey olmaz demesi yüzünden heba olduk. Herkesin kolayca kazandiğı fakültelere uzaktan baktık. Ekonomik özgürlügü̈müzün olmayışı nedeniyle hayatımı hep zayıf, pasif, başkasına muhtaç olmakla geçecek.

"Kendi İsteklerini Gerçekleştirme / Gerçekleştirememe" teması bağlamındaki görüşlerine bakıldığında; evlilik öncesinde anne babalarının, evlilik sonrasında da eşlerinin ve çocuklarının isteklerinin daha ön planda olduğu izlenebilir. Evlenmeden önce çoğunun üzerinde ailelerinin etkisinin olması, istedikleri eğitimi alamamaları, ekonomik bağımsızlıklarının olmayışı, çocuklarının bakımının yaşları nedeniyle yoğunluğu ve eşlerinin etkisi nedeniyle kendi isteklerini yeterince gerçekleştirmedikleri söylenebilir.

\section{“Söz Hakkı Olmama / Değer Görmeme” Teması}

Çalışmada katılımcıların "Söz Hakkı Olmama / Değer Görmeme” teması altında ele alınabilecek kimi görüşleri şöyledir.

K.2: Kocam her fikrini, her yapacağımızı ve yaşadığımızı anne ve kardeşleriyle paylaşıp, beni aşağılayıp, horlayıp durdular, her eziyeti yaptılar. Babam anneme kızar diye yuttum kimseye söyleyemedim.

K.3: Kendimi bildiğimden bu zamana kadar istediğim hiçbir şey üzerinde söz hakkım olmadı. Eşimden ayrlldıktan sonra, ben kendim istediğim halde ailem onay verene kadar ailemin evine gelemedim. Söz hakkım yok uyku uyuyamıyorum.

K.7: Maalesef ilkokul öğretmenimiz de ayrımcılı̆̆lyla, dayă̆ıyla, sevgisizliğiyle geleceğimize kara çalmış oldu.

"Söz Hakk1 Olmama / Değer Görmeme" temas1 altında ifade edilen görüşler irdelendiğinde; katılımcıların yaklaşık yarısının evlilik öncesinde aileleri karşısında, evlendikten sonra da eşleri karşısında söz hakkı sahibi olmadıkları ve yakın çevresindekilerden değer görmedikleri söylenebilir.

Genel olarak bakıldığında; katılımcıların kendilerini, isteklerini, mutluluklarını öncelikle çocukları sonra eşleri için ikinci plana attıkları söylenebilir. Özellikle çocuklarının bakımının istekleri ve kendi yaşamlarının çok önünde olduğu anlaşılıyor. Kuşkusuz anne olarak çocuklarının bakımı ile (ki baba da ilgilenmeli) ilgilenmeleri ya da evlerine, eşlerine destek olmaları gerekiyor; tüm bunların bilincinde oldukları da anlaşılıyor. Ama bunları yaparken kendi isteklerini, düşüncelerini, mutluluklarını ikinci planda tuttuklarını, kendilerine yeterince zaman ayırmadıklarını düşündükleri görülüyor.

$\mathrm{Bu}$ veriler 1 şığında, katılımcıların içinde bulundukları durumu dile getirebildikleri ve bu durumun farkında olduklarını söylemek mümkündür. 


\section{Görüşmeden Elde Edilen Verilerin Değerlendirilmesi}

Altıncı oturumun sonunda katılımcılarla iki grup halinde atölye sürecine ilişkin görüşmeler yapılmıştır. Görüşmelerde elde edilen katılımcı görüşleri incelenmiş ve bu inceleme sonunda da ulaşılan veriler "Kadın Olmak", "Kendimize Ayırdığımız Özel Zaman ve İşler", "Üzerinde Durulan Kavramlar" ve "Yaratıcı Drama" olmak üzere dört tema altında açıklanmaya çalışılmıştır.

\section{"Kadın olmak" Teması}

K. 1: Kadın olmak demek güçlü olmak demek. Güçlü olmak zorunda olmak demek.

K. 2: Çok saburlı olmak ve geniş yürekli olmak demek.

K. 3: Güçlü olmak demek.

K. 4: Kadın olmak hem anne olmak hem baba olmak hem eş olmakyani her şey olmak demek hayatta. Çok şey olmak demek.

K. 5: Kadın olmak gurursuz olmak demek. Neden, çünkü kadın ekonomik özgürlü̆̈̈̈ olmadiğı için aldatan kocasına göz yummak zorunda kalıyor. Adam her türlü aşağılamayı yapıyor ama kadın onu sinesine çekip oturabiliyor.

K. 6: Buna kadının yaşadığı çaresizlik diyebiliriz belki ama gurursuzlığu değil bu kadının.

K. 7: Kadın çocuğu için katlanıyor birçok şeye. Ben de birçok defa çekip gitmek yeni bir başlangıç yapmak istedim ama ha bu çocuk büyüyecek, ha ne olacak diye hep vazgeçtim.

K. 5: Kadınla ilgili bir diğer şey de toplumdaki namus kavramı.

"Kadın Olmak" teması altında toplanan katılımcı görüşleri incelendiğinde, güçlü olmak ifadesinin öne çıktığı görülüyor. Bununla birlikte, sabırlı olmak, geniş yürekli olmak, her şey olmak ifadeleri de belirtilmiştir. Görüşme sırasında, kadının ekonomik özgürlüğünün olmamasının onu çaresizliğe ittiği de vurgulanmıştır. Ayrıca toplumumuzdaki namus kavramının sadece kadını işaret etmesi de önemli bir sorun olarak düşünülüyor.

\section{“Kendimize Ayırdığımız Özel Zaman ve İșler” Teması}

K2: Şöyle büyük oğlan sonra klz derken örneğin bir spor salonuna gitmek olsun ya da kendime özel vakit ayırmak olsun, bunlara zaman bulamiyordum. O zaman bir türlü olmuyordu. Amma velakin sizinle birlikte buraya iki saat zaman ayırdım. Şunu fark ettim, ben istersem bu iki saati kendime ayırabilirmişim.

K9: Ben de ayıramıyorum. Bu çalışma belki de bizimle ilgili olduğu için konular, kadınla ilgili olduğu için bizi çok etkiledi herhalde.

K7: Kerem doğana kadar her şey daha rahattı. Kerem'den sonra, son 5 ylldır ben her şeyimi Kerem'e verdim. ... Ben bunun eksikliğini de hiç hissetmedim ilginç olan da bu. Yani ben kendime vakit ayırmıyorum demedim hiç. ... geçen akşam arkadaşlarım geldi; oturuyoruz bahçede, sohbete başladık. Ben bu dramadan falan bahsettim. Sonra anlatırken anlatırken arkadaşlarım, ne kadar güzel, hayatında güzel değişiklikler olmuş dediler. O zaman fark ettim. Evet yani son bir haftadır kendim Kerem'siz, .......... ’siz (eşi) de eğlenebiliyormuşum. Ben en fazla kuaföre giderim oda bir saattir. Onda bile Keremi düşünürüm.

K6: Evet ben de hep bizim oğlanı düşünürdüm her yerde. 
K7: Burada zaman çok çabuk geçti ve ben bunun güzel bir şey olduğunu, kendine zaman ayırmak gerektiğini fark ettim. Bunun eksikliğini buraya katılınca akşamki sohbette fark ettim. Yapmam gerekiyormuş. Güzel de oluyormuş.

K4: Ben de mesela çocuklar okuldayken hemen ev işleri yemekle falan ilgilenirdim. Aman onlar gelmeden yemeği yapayım. Bu 6 gündür evim pislikten battı ama hiç içimden yapasım da gelmedi. Sadece çocukların okuldan gelince atıştıracaklarını bir gece önceden yapıyorum ve demek ki oluyormuş.

K3: Karşıda bir halk eğitim merkezi olduğunu ben mesela bakışım değişince yeni fark ettim.

K8:Aslında biz temizliği bile kendimizden çok çat kapı biri gelirse diye, yani yine başkalarına yapıyoruz.

"Kendimize Ayırdığımız Özel Zaman ve İşler" teması altında katılımcı görüşleri ele alındığında; katılımcıların çoğunun kendilerine yeterince zaman ayırmadıkları, bunun neredeyse doğal olarak görüldüğü, çocuklara ve ev işlerine çok zaman ayırdıkları ve bu çalışma ile birlikte kendilerine zaman ayırabileceklerini ve bunun da (hatta çocukların bakımını ve ev işlerini engellemeden) olabileceğini gördükleri söylenebilir.

\section{"Üzerinde Durulan Kavramlar" Teması}

K1: Kendine güven.

K8: Kadının fedakarlı̆̆l, kendini feda etmesi.

K9: Kadının bilinmesi.

K10: Kendini ifade etme, var etme.

K4: Kadının ezildiğinin fark edilmesi.

K1: Hayır diyebilmek

K2: Kendini mutlu etmek, kendini fark etmek

“Üzerinde Durulan Kavramlar” teması altında ele alınan katılımcı görüşlerinde, katılımcıların birbirlerini tamamlayacak şekilde kadının kendine dönük ifadelerini sıraladıkları ve bunları öne çıkardıkları görülür.

\section{"Yaratıcı Drama" Teması}

K7: Yakın şeyler ama daha çok ben drama deyince tiyatro gibi bir şeyler düşünmüştüm. Doğaçlamalar olacă̆ını hiç ummamıştım.

K4: Bende siz söyleyeceksiniz biz de yapacağız diye düşünmüştüm, ama burada biz bulduk birçok şeyi.

K9: Ben daha çok sizin bilgiler vereceğiniz bir çalışma sanıyordum. Siz bize şöyle yapmalısınız, bu iyidir gibi şeyler anlatacaksınız diye düşünmüşü̈m.

K3: Sizden dinlemek farklı olurdu. Iç̧inde yaşamak çok daha iyiydi.

K10: Dün gece çok hastaydım ve neredeyse hiç uyumadım ve buraya geldim. Dersin sonunda şu an hiçbir şeyim kalmadı. Dikkatimi tamamen buraya verince diğer sıkıntılar gidiyor.

K8: Şimdi ne olacak diye düşünüyorum. Alışmıştık her gün hem oyna hem tartış... iyi bir zihin jimnastiği oluyordu. 
"Yaratıcı Drama" teması altında bir araya getirilen katılımcı görüşlerinde, önce yaratıcı dramanın tiyatro ile karıştırıldığı ama sonra uygulamalarla ne olduğunun anlaşıldığı ortaya çıkıyor. Özellikle sürecin uygulamalı olmasından ve kendilerinin aktif katılmalarından hoşlandıkları anlaş1liyor.

Bu veriler açısından bakıldığında, katılımcıların kadın olarak güçlü olduklarını ve kendilerine zaman ayıramadıkları ama ayırmaları gerektiğini vurguladıkları izleniyor. Özellikle, "üzerinde durulan kavramlar” temasına bakıldığında sürecin sonunda kadın kimliğine ilişkin ifadelerin değiştiği düşünülebilir.

\section{Sonuç}

Çalışmanın başlangıcında, katılımcıların kadın kimliğine yüklenen toplusal cinsiyet rolleri ile ilgili (çocukların bakımı ve yetiştirilmeleri, ev işleri, eşe destek, başka bir işte çalışmama, fedakarlık, sorumluluk, şefkatli olmak vb.) ifadelerinde, yüklendikleri rollerin olağan, doğal olarak kabul ettikleri söylenebilir.

Uygulamalarla birlikte, katılımcıların kadın kimliklerine yüklenen rolleri gerçekleştirirken kendi isteklerini, beklentilerini, mutlulukların göz ardı ettikleri, erteledikleri ya da ikinci plana attıkları ortaya çıkmıştır. Bu durumdan rahatsız oldukları ve bir kısmının mutsuz olduğu yazılan mektuplarda ve son oturumda yapılan görüşmelerde belirtilmiştir.

Katılımcılar, günlük yapmaları gereken işleri, kendilerine zaman ayırarak da yapabileceklerini gördüklerini ve bu durumun kendilerini daha mutlu edeceğini son oturumda dile getirmişlerdir.

Çalışmanın sonunda, kadın kimliği ile ilgili başlangıçta ifade edilen görüşlerin değiştiği ve atölye süreçlerindeki etkinliklerde yeni görüşlerin ifade edildiği görülmüştür. Son oturumda katılımcılar tarafından dile getirilen "kendine güven", "kadının fedakarlığı", "kendini feda etmesi", "kadının bilinmesi", "kendini ifade etme", "var etme", "kadının ezildiğinin fark edilmesi” ve "hayır diyebilmek" vb. ifadeler, katılımcı görüşlerinin değişimine örnektir.

“Küçük Kız” öyküsü, kadın kimliğinin ve üstlendiği rollerin ele alınmasında ve katılımcıların kendi yaşantılarını fark etmelerinde, karşılaştırma ve değerlendirme yapmalarına olanak sağlamıştır.

Yaratıcı drama yöntemi, katılımcılara kadın kimliği konusunu, yaşayarak deneyimlemelerini sağlamıştır. Katılımcılar, yaşayarak oynamalarının daha iyi olduğunu belirtmişlerdir. Yaratıcı drama yönteminin, katılımcıların kendi yaşantılarını ortaya çıkarmaları, diğer katılımcıların yaşantılarıyla karşılaştırmaları, değerlendirmeleri ve konunun farklı yönlerinin irdelenebilmesi açısından kadın çalışmalarında yararlı ve uygun bir yöntem olduğu söylenebilir.

\section{Öneriler}

Çağdaş Drama Derneği ve yaratıcı drama alanıyla ilişkili kurum ve kuruluşların kadınlara yönelik atölyeler açmaları ve yaygınlaştırılmaları; kadın atölyelerinin yanı sıra, kadın çalışmalarıyla ilişkili konularda erkeklerin eğitimine yönelik atölyelerin de açılması ve yaygınlaştırılması, ayrıca çeşitli kurumlar tarafından kadın çalışmaları çerçevesinde yürütülen çalışmalarda, projelerde, eğitim etkinliklerinde yaratıcı drama yönteminden yararlanılması önerilir. 


\section{Kaynakça}

Adıgüzel, Ö. (2012). Eğitimde yaratıcı drama. Ankara: Pegem Yayınları.

Dökmen, Z.Y. (2010). Toplumsal cinsiyet sosyal psikolojik açıklamalar. İstanbul: Remzi Kitabevi.

Güldü, Ö., Ersoy Kart, Müge. (2009). Toplumsal cinsiyet rolleri ve siyasal tutumlar. Ankara Üniversitesi Siyasal Bilgiler Fakültesi Dergisi. Cilt: 64, Sayı: 3, s. 97-116.

Kuzgun, Y., Sevim, S.A. (2004). Kadınların çalışmasına karşı tutum ve dini yönelim arasındaki ilişki. Ankara Üniversitesi Eğitim Bilimleri Fakültesi Dergisi. Cilt: 37, sayı: 1, s.14-27.

Sharafeddine, F. (2012). Küçük kız. (Birinci Baskı). İstanbul: Erdem Yayınları.

Üstündağ, T. (2006). Günümüz eğitiminde dramanın yeri. Yaratıcı Drama 1985-1998 Yazılar (Edt. Ömer Adıgüzel). Ankara: Naturel Yayınları.

Vefikuluçay Yılmaz, D., Zeyneloğlu, S. vd. (2009). Üniversite öğrencilerinin toplumsal cinsiyet rollerine ilişkin görüşleri. Uluslararası İnsan Bilimleri Dergisi. Cilt:6, Sayı:1, s.775-792.

\section{EK1}

\section{“Küçük Kız” Öyküsünün Özeti}

Fatıma Sharafeddine'nin "Küçük Kız” adlı hikâyesi kısaca şöyledir:

Hikâye, "Bu hikâyeye inanmayabilirsin ama gerçek bir hikâye bu. Hikâye insanlara her şeyi vermek isteyen bir kız hakkında. Bu kız, 'vermek insana kendini iyi hissettiriyor' diyordu”, diye başlar. Her şeyi vermek isteyen kız, çok sevdiği flütünü, sürüsünü bununla çağırsın diye bir çobana verir. Mavi atkısını, rüzgarda üşüyen bir arkadaşına verir. S1kıldığını düşündüğü komşunun köpeğine sarı topunu verir. (...) Küçük kız her şeyini başkalarına verir ama kendisinin ne istediğini hiç düşünmez. Küçük kız, anne babasını da memnun etmek ister. Aradan yıllar geçer, küçük kız artık büyümüştür. Başka bir ülkeye gidip orada yaşamak ister ama anne ve babasının üzüleceğini düşünür. Çalışacak yaşa geldiğinde, babasının mutlu olasını istediği için babasının firınında çalışmaya başlar. Aradan uzun yıllar geçer, evlenecek yaşa gelir. Annesi mutlu olsun diye annesinin bulduğu bir adamla evlenir. Şimdi de kocasını mutlu etmek için güzel yemekler pişirir, tarladan buğday toplar, her işte kocasina yardım eder.

Genç kadın hep başkalarını memnun etmeye çabalamaktan artık yorulur. Sonunda bir şeyi fark eder; "etrafımdaki herkes beni seviyor ve mutlu görünüyorlar ama neden mutlu değilim. Düşünür, düşünür... Tam o sırada ilk defa kendisini düşündüğünü fark eder. "Ben ne istiyorum?” der kendi kendine. Ne istediğini bulana kadar düşünür. Çok sevdiği flütü aklına gelir ve "Flüt çalmak istiyorum!" diye bağırır. Flütümle ezgiler çalarak dünyayı gezmek istiyorum, der. "Fırın ne olacak?" diyen babasına, yardım edecek başkasını bulabilirsin; "Ya kocan ne olacak?" diyen annesine; kendisine bakmayı öğrenir, der. "Buğday toplamada kim bana yardım edecek?" diyen kocasına; seyahatim fazla uzun sürmez, geri geleceğim ama tüm bunları kendin yapman gerekiyor, der.

Her şeyi başkalarına vermek ve herkesi mutlu etmek isteyen küçük kız, meşhur bir flütçü olur ve bu onu çok mutlu eder. O mutlu olduğu için de çevresindekiler öncekinden çok daha mutlu olurlar. 